\title{
Analysis of the echolocation calls and morphometry of a population of Myotis chiloensis (Waterhouse, 1838) from the southern Chilean temperate forest
}

\section{Gonzalo Ossa ${ }^{1}$, José Tomás Ibarra ${ }^{1}$, Kathrin Barboza ${ }^{2}$, Felipe Hernández ${ }^{1}$, Nicolás Gálvez ${ }^{1}$, Jerry Laker ${ }^{1}$ and Cristián Bonacic ${ }^{1}$}

${ }^{1}$ Laboratorio Fauna Australis, Programa de Recursos Naturales, Facultad de Agronomía e Ingeniería Forestal, Pontificia Universidad Católica de Chile. Vicuña Mackenna 4860, Macul, Casilla 306 - 22, Santiago, Chile.

${ }^{2}$ Centro de Estudios en Biología Teórica y Aplicada, Programa para la Conservación de los Murciélagos de Bolivia. Box 9641, La Paz, Bolivia.

\begin{abstract}
G. Ossa, J.T. Ibarra, K. Barboza, F. Hernández, N. Gálvez, J. Laker, and C. Bonacic. 2010. Analysis of the echolocation calls and morphometry of a population of Myotis chiloensis (Waterhouse, 1838) from the southern Chilean temperate forest. Cien. Inv. Agr. 37(2): 131-139. Echolocation is characteristic of bats of the suborder Microchiroptera. Though recent studies of echolocation calls in Latin America have generated significant advances in knowledge about distribution, habitat use and ecology of bats, the recording and analysis of bat calls is barely known in Chile. As a first step in studies on the ecology of the endemic Chilean myotis bat (Myotis chiloensis), we carried out morphometric measures and analyzed echolocation calls in a rural site near Pucón $\left(39^{\circ} 15^{\prime} \mathrm{S} 17^{\circ} \mathrm{W}\right)$ in the Araucanía Region of southern Chile. During January 2009, we obtained 22 records from captured and 75 records from flying individuals. The analysis of calls in searching phase showed that the terminal frequency for this species is $43.4 \pm 1.2 \mathrm{kHz}$, with a mean duration of $2.1 \pm 1.0 \mathrm{~ms}$ and an interval between pulses of $77.5 \pm 16.9 \mathrm{~ms}$. The calls are FM - QCF, as is characteristic for the family Vespertilionidae. The contribution of new morphometric data from captured and released individuals indicates differences from previous studies. The records and acoustic analysis establishes a baseline for more detailed future ecological investigation of this and other bat species in Chile.
\end{abstract}

Key words: Myotis chiloensis, echolocation, morphometrics, bats, Chiroptera, temperate rainforest, Chile.

\section{Introduction}

Chiropterans (bats) are known to provide significant services to agriculture, especially for controlling pest insects, pollinators and seed

Received: July 06, 2009. Accepted: October 30, 2009. Corresponding author: gossa@uc.cl dispersers (Wickramasinghe et al., 2004; Cleveland et al., 2006; Federico et al., 2008). In Chile, knowledge of bats is largely based on individuals captured in mist nets (Solís, 2008). However, this method shows a noticeable bias for species of the Phyllostomidae family and other low flying species (Siles and Terán, 2007; Barboza et al., 2006).

An alternative method to study bats, that is potentially less biased, involves detection of the ultra- 
sonic echolocation calls that the Microchiroptera use for night-flight guidance (Kalko and Schnitzler, 1993; Kunz and Racey, 1998). Echolocation was first described by Griffin (1938), and extensively updated by Korine and Kalko (2001).

Bats emit pulses of ultrasound and compare these pulses with patterns of echoes generated by the environment. These echoes rebound off solid objects or prey, providing detailed information about distance, shape, size, etc., and bats change the frequency, amplitude and time of their calls depending on the precision required (Neuweiler, 2000; Schnitzler and Kalko, 2001; Schnitzler et al., 2003). Bat species have developed different types of calls, according to the different environments they inhabit, the prey available and the characteristic development of each species and their particular auditive systems (Kalko and Schnitzler, 1989; Kalko and Schnitzler, 1993; Korine and Kalko, 2001).

The frequency range, shape and duration of the calls varies between species (Murray et al., 2001). The calls are usually characterised as three phases (Neuweiler, 2000; Schnitzler et al., 2003; Siles and Terán, 2007): a) Search calls: to detect prey, with a narrow frequency range and a longer duration; b) Approximation calls, with increased frequency range and shorter duration; and c) Calls of terminal phase (Feeding Buzz), heard when a bat attempts to capture prey, with decreased frequency range and minimum duration (Kalko and Schnitzler, 1989). This last phase is not observed in bats that obtain their food from the ground, like some Myotis spp., as in this case, they are guided by the sounds emitted by the prey (Arlettaz et al., 2001). The terminal phase is typical of species specialised in hunting airborne prey (Siemers and Schnitzler, 2004).

Monitoring of bat echolocation calls requires equipment able to record ultrasound in audible formats, using time expansion and/or heterodyne conversion (Walsh and Catto, 2004). The analysis of these calls is helpful for the recording known species (Ahlén and Baagoe, 1999), the determination of new species that are difficult to capture with traditional methods (LaVal and Rodríguez-H., 2002), the development of studies on the ecology of foraging behaviour (Kalko and Schnitzler, 1989; McCracken, 1996), and activity patterns (Barboza et al., 2006; Barboza et al., 2009), among others.

In Chile, 11 bat species have been described, all belonging to the suborder Microchiroptera, with six of them belonging to the Vespertilionidae family, of which two belong to the genus Myotis (Canals and Cattan, 2008; Iriarte, 2008). The members of this family are small, presenting a face free from visible ornaments as leafed nose (Vargas, 2007), uropatagium or a welldeveloped tail membrane, and have a mainly insectivorous diet (Moya et al., 2007).

Myotis chiloensis (Waterhouse, 1838) is found in shrubland, savannah and temperate rainforest environments of Chile (extending from the Region of Coquimbo to Cape Horn) and Argentina (in the provinces of Chubut and Neuquén). It bat with the most southerly distribution recorded to date (Mann, 1978; Galaz et al., 2009; Galaz and Yáñez, 2006). During daytime, it hides in a wide range of sites, such as bark fissures, the roofs and walls of houses and rocky caves (Iriarte, 2008). Like the rest of the species described in Chile, its echolocation calls have not until now been recorded (Solís, 2008).

A study was developed to record and analyze the ultrasound calls emitted by M. chiloensis in a rural zone of the temperate forests, as a first step in creating an acoustic data base to support the monitoring and study of bats in Chile. In addition, new morphometric data are presented obtained from live individuals, which are compared to morphometric data from previous studies.

\section{Materials and methods}

Acoustic calls and morphometrics of M. chiloensis were studied during the summer of 2009, in a rural sector of the Pucón comuna $\left(39^{\circ} 15^{\prime} \mathrm{S}\right.$ $17^{\circ} 45^{\prime}$ O), IX Region of Araucanía, Chile.

The study site was located in a zone of horticultural cultivation and fruit trees set in a predominantly wooded matrix. The area is 
adjacent to the high-elevation El Cañi Nature Sanctuary, which includes 500 ha of native forest of four species of Nothofagus and Araucaria araucana (MacAdam et al., 1996). The area has a high rainfall temperate climate with Mediterranean influence, where the precipitation is distributed through the whole year, reaching its peak during the winter period. The annual average temperature is $9.7^{\circ} \mathrm{C}$ (Di Castri and Hajek, 1976).

A small colony of bats in the roof space of a house was identified. Two mist nets were set up, (3 and $6 \mathrm{~m}$ long), at $1 \mathrm{~m}$ from the soil and at a distance of $2 \mathrm{~m}$ from the house during a period of 5 days, for a 2-hour period per night. In all, we carried out a total capture effort of 90 net linear metre hours. The captured bats were placed in cloth bags and were determined as $M$. chiloensis, using the key proposed by Galaz and Yáñez (2006). Then, morphometric measurements were made of nine individuals captured, with a $0.1 \mathrm{~cm}$ caliper and a $100 \mathrm{~g}$ spring balance scale, according to the methodology used by MitchellJones and McLeish (2004).

For the recording of echolocation calls, the method chosen by Barboza et al. was used, (2006). A Pettersson D240X bat detector was used (Pettersson Elektronik AB, Uppsala) in
10X-expanded mode, connected to a Edirol professional digital recorder by Roland R-09, set to record WAV audio files. To record flight calls, one person would set a bat free, while another, standing 5m away, would record the bat calls in search phase. Recorded calls were analyzed later using Avisoft SASLab Pro 4.51 Software (R. Spetch, Germany), using a 44.1 $\mathrm{KHz}$ sampling frequency, FFT 256 length, Hamming type window and $75 \%$ of overlapping. The best quality files recorded from the individuals captured in the nets were used for the calls characterization.

\section{Results}

We captured 12 bats using the mist nets, of which 11 were found to be $M$. chiloensis, the other was identified as Tadarida brasiliensis. Capture effort for M. chiloensis was 0.12 captured individuals / $\mathrm{H} / \mathrm{m}$ red.

\section{Morphometrics}

The average values $\pm \mathrm{DS}$, in $\mathrm{mm}$, for: total length (T.L.), tail length (T.L.), foot length (L.Pp.), ear (E), tragus (T), forearm length (F.L.), uropatagium length (L.U.) and weight (P) are detailed in

Table 1. Comparison between the morphometric measurements collected and those reported in other Myotis chiloensis studies.

\begin{tabular}{|c|c|c|c|c|c|}
\hline Measures & $\begin{array}{c}\text { Ossa et al., } \\
\text { (collected data) } \\
(\mu \pm \text { DS })\end{array}$ & $\begin{array}{c}\text { Galaz and Yáñez, } \\
2006 \\
(\mu)\end{array}$ & $\begin{array}{c}\text { Canals and } \\
\text { Cattan, 2008 } \\
\text { (Range) }\end{array}$ & $\begin{array}{l}\text { Canals et al., } 2001 \\
\qquad(\mu \pm D S)\end{array}$ & $\begin{array}{c}\text { Mann, } 1978 \\
\text { (Range) }\end{array}$ \\
\hline Number of individuals & 9 & - & - & 49 & - \\
\hline Total length (mm) & $71.7 \pm 6.2$ & 86.3 & $95-98$ & - & $94-97$ \\
\hline Tail length (mm) & $28.7 \pm 4.1$ & 38.4 & 43 & $36.3 \pm 6.0$ & $42-44$ \\
\hline Foot length (mm) & $7.2 \pm 0.9$ & - & - & - & - \\
\hline Ear $(\mathrm{mm})$ & $9.5 \pm 1.9$ & 12.3 & - & - & - \\
\hline Tragus (mm) & $4.8 \pm 1.0$ & & - & - & - \\
\hline Forearm length (mm) & $38.5 \pm 1.6$ & 37.3 & - & $38.2 \pm 1-4$ & $36-40$ \\
\hline Uropatagium (mm) & $28.7 \pm 4.1$ & - & - & - & - \\
\hline Weight (g) & $6.4 \pm 0.7$ & $6.58 \pm 0.5$ & 8 & - & - \\
\hline
\end{tabular}


Table 1. Additionally, the morphometric values reported in previous studies for M. chiloensis in Chile are presented.

\section{Acoustic monitoring}

A total of 22 audio files were obtained from the 11 captured individuals. A further 75 files were recorded of wild bats at the capture site. The 12 files with the best recording quality were used for the analysis of the captured individuals. These calls include the search, approximation and terminal phases (Figure 1).

The analysis of the echolocation calls in search phase is presented in Figure 2. This analysis showed an average frequency of $43.4 \pm 1.2 \mathrm{kHz}$, with a duration of $2.1 \pm 1.0 \mathrm{~ms}$ and interval between pulses of $77.5 \pm 16.9 \mathrm{~ms}$. Calls are composites of both FM (Frequency modulation) and QCF (Quasi-Constant Frequency). In the initial FM phase, a wide variation in the frequency is observed over a short period of time. During the second QCF phase, the call 1remains in a very limited frequency range for a longer period of time.

\section{Discussion}

This study provides new morphometric information and, for the first time in Chile, the echolocation calls of M. chiloensis are described and analyzed.

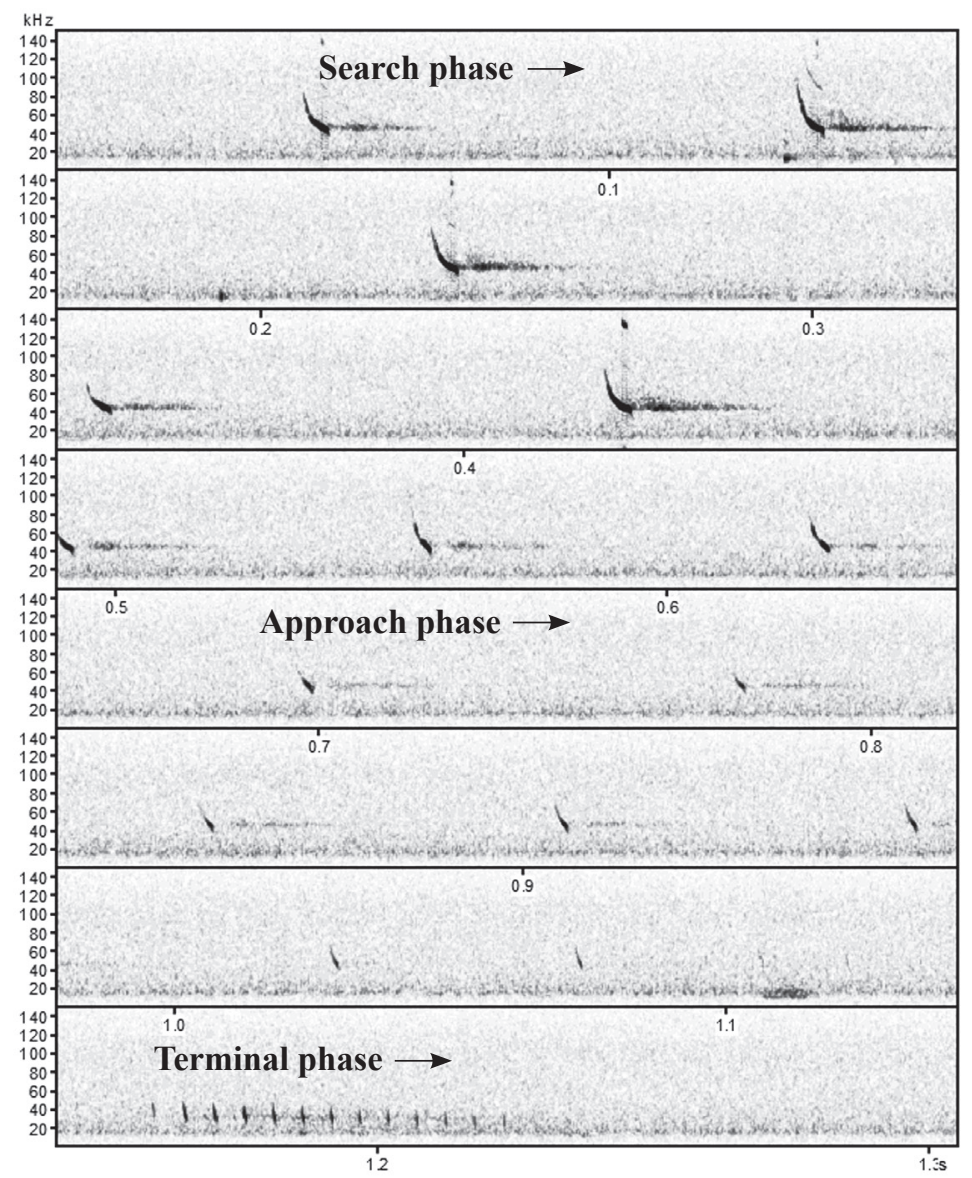

Figure 1. Complete sonogram of a Myotis chiloensis call - Search phase, Approach phase and Terminal phase (or Feeding buzz). The analysis used Software Avisoft SASLab Pro 4.51 (R. Spetch, Germany), $44.1 \mathrm{kHz}$ sampling frequency, 256 FFT length, Hamming window and $75 \%$ overlap. 


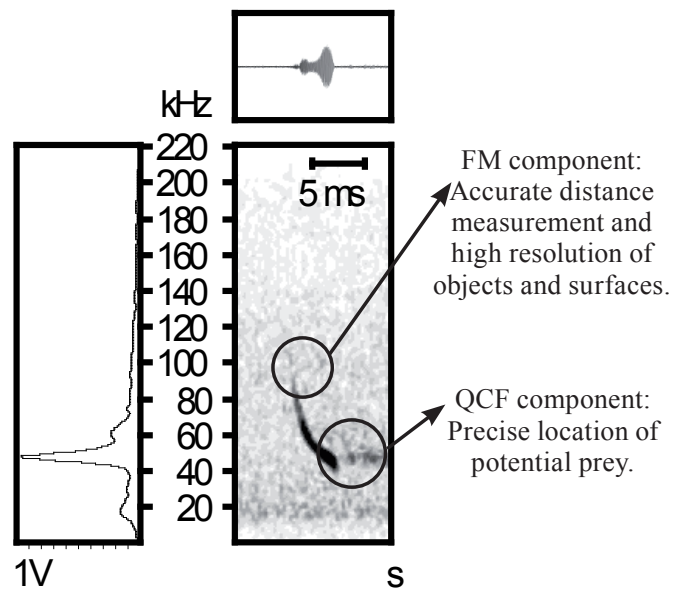

Figure 2. Analysis of a typical Myotis chiloensis search phase call. The terminal frequency value is $43.0 \mathrm{kHz}$, and its duration is $2.0 \mathrm{~ms}$. The figure explain the two components of the call (FM and QCF).

\section{Morphometrics}

Measurements of total length and tail length obtained from the captured individuals were outside ranges published by other studies (Canals and Cattan, 2008; Galaz and Yáñez, 2006; Canals et al., 2001; Mann, 1978). This could occur because the values described by those studies were obtained from embalmed individuals, and thus may have experienced some variation as a result (Torres-Mura, personal communication). Alternatively, the variations might be due to geographical variation in this species (Canals et al., 2001), or indeed to the difficulty of taking accurate morphometric measurements from live bats in the field, especially when the measurements include the uropatagium (in which the tail of these species is embedded). The standard deviation of the measurements of total length $(71.1 \pm 6.2)$, tail length $(28.7 \pm 4.1)$ and uropatagium length $(28.7 \pm 4.1)$ indicates the high variability in the measurements. Likewise, the values obtained for the forearm length $(38.5 \pm 1.6)$ and weight of the individuals $(6.4 \pm 0.7)$, are similar to the values reported by other authors, such as Canals et al. (2001) (L.A. $38.2 \pm 1.4$ ), Galaz and Yáñez (2006) (L.A. 37.3; P. $6.58 \pm 0.5$ ) and Mann (1978) (L.A. 36-40). These measurements are easier in the field and have lower standard deviation.
Some data are reported in this study, such as right foot length $(7.2 \pm 0.9)$ and tragus length $(4.8 \pm 1.0)$ that have not been described in literature. They represent new morphometric records for this species.

The implication of the differences recorded in the morphometric data is that either there exists more than one subspecies or that there is incompatibility between the in vivo measurements and the measurement of dead, preserved specimens. Accordingly, the development of a protocol that allows standardizing the measurements is still necessary, to make reliable comparisons throughout the country.

\section{Acoustic monitoring}

Calls in search phase were used for acoustic analyses (Fenton and Bell, 1981; Parsons and Jones, 2000; Kalko and Aguirre, 2007), because they represent $90 \%$ of the calls emitted by bats during foraging (Fenton et al., 1977).

The calls for M. chiloensis were determined to be of FM - QCF type, which are characteristic of species foraging in environments with obstacles like forest borders or clearings (Kalko and Schnitzler, 1993; Schnitzler and Kalko, 2001; Kalko and Aguirre, 2007). These bats capture flying insects and have the agility to navigate between obstacles (Schnitzler and Kalko, 2001). The FM component allows bats to detect objects precisely, as long as they are not very small (Schnitzler et al., 2003). FM is used to navigate, measure distances and avoid obstacles, achieving a high resolution of objects and surfaces (Kalko and Aguirre, 2007). On the other hand, the quasi-constant frequency corresponds to an adaptation of the component of constant frequency (CF), which is used to differentiate insects from dense vegetation. The quasi-constant frequency is used to locate insects in open environments, away from obstacles (Schnitzler and Kalko, 2001). The calls with $\mathrm{CF}$ component are long $(>30 \mathrm{~ms})$, in comparison to those QCF ( $<20 \mathrm{~ms})$, and both rely on the beating of the insect's wings to produce an "acoustic mirror" (Kalko and Aguirre, 2007). The strength of the echo will depend on 
the angle of the insect wings relative to the direction of the bat (Kalko and Aguirre, 2007). As the CF component is extended over time, the echo contains several flapping cycles of the insect, indicating its position and speed (Kalko and Aguirre, 2007).

Only the terminal frequency of $M$. chiloensis was measured in this study, as Vespertilionidae and other families using FM components are easier to recognize through the lowest frequency calls, specifically at the end of the FM component (Fenton and Bell, 1981). This is because the lowest frequencies are less subject to atmospheric attenuation (Kalko and Schnitzler, 1989). Therefore, a bat with FM type calls passing at seven meters from the microphone will have an initial frequency lower than one bat passing at three meters (Fenton and Bell, 1981).

A negative relation has been described between the frequency of the calls in search phase and the size of the bat (Jones, 1999). The small $M$. chiloensis, weighing around $6 \mathrm{~g}$, operates at high frequency.

\section{Conclusions}

The acoustic analysis allowed us to describe the distinctive characteristics of the calls of M. chiloensis and has improved our ability to identify this species reliably in the field. We were able to record some basic information about behavioural ecology, observing it to hunt low around vegetation.
Use of ultrasound detectors opens the possibility to record new species flying higher and that are still undetected by traditional methods (Barboza et al., 2009). The creation of a complete ultrasound library of the bat species present in the country is still necessary. Once established, we will be able to make a more complete record of the distributions of the different chiropterans present in Chile.

\section{Acknowlegments}

This study was financed by the Darwin Initiative (Project ref-15/006) and by Wildlife Trust Alliance. We thank Manuel Venegas of Guias del Cañi for his invaluable support in the field, and Fundación Lahuén, owners of the Cañi Nature Sanctuary. We thank Sr. Miguel Martínez and his family, for his hospitality and for providing his bat house-shelter where the captures and recordings were made. We acknowledge the support of the Agriculture and Livestock Service (SAG Diproren). Also thanks to Juan Carlos Torres-Mura of the Museo Nacional de Historia Natural for allowing access to the literature and for his comments during the terminal phase of this study. Special thanks to Luis F. Aguirre from BIOTA, Cochabamba, Bolivia, for his constant enthusiasm and support in the use of ultrasound equipment for the study of bats in Latin America. Finally, to all the members of the Fauna Australis Wildlife Research Laboratory for their support and motivation while carrying out this and other projects in the Araucanía Region. 


\section{Resumen}

G. Ossa, J.T. Ibarra, K. Barboza, F. Hernández, N. Gálvez, J. Laker y C. Bonacic. 2010. Análisis de las llamadas de ecolocación y morfometría de una población de Myotis chiloensis (Waterhouse, 1838) del bosque templado del Sur de Chile. Cien. Inv. Agr. 37(2): 131-139. El sistema de ecolocación es característico de los murciélagos del suborden Microquiróptera. A pesar de que el estudio de este sistema ha generado significativos avances en el conocimiento de la distribución, uso de hábitat y ecología de murciélagos en Latinoamérica, el registro y análisis de las llamadas de las especies de Chile aún es incipiente. Con el objetivo de ampliar el conocimiento actual de Myotis chiloensis, se realizaron mediciones morfométricas y análisis de sus llamadas de ecolocación en un sector rural periférico a la ciudad de Pucón $\left(39^{\circ} 15^{\prime} \mathrm{S} 17^{\circ} \mathrm{W}\right)$, Región de la Araucanía, sur de Chile. En enero de 2009, fueron obtenidas 22 grabaciones de llamadas de individuos capturados y 75 llamadas de individuos en vuelo. El análisis de las llamadas en fase de búsqueda indica que la frecuencia promedio característica para esta especie es $43.4 \pm 1.2 \mathrm{kHz}$, con una duración promedio de $2.1 \pm 1.0 \mathrm{~ms}$ y un intervalo entre pulsos de $77.5 \pm 16.9 \mathrm{~ms}$. Los componentes que se observan en las llamadas de búsqueda para esta especie, son de Frecuencia Modulada (FM) y Frecuencia casi Constante (QCF), las que son características de la familia Vespertilionidae. El aporte de nuevos datos morfométricos de los individuos capturados y liberados en el área indican diferencias respecto a estudios anteriores. Los registros y análisis acústicos de este murciélago endémico del sur de Sud América, generan nuevas oportunidades para el estudio de su ecología y la de otras especies en Chile.

Palabras clave: Myotis chiloensis, ecolocación, morfometría, murciélagos, Chiroptera, bosques templados, Chile.

\section{References}

Ahlén, I., and H.J. Baagoe. 1999. Use of ultrasound detectors for bat studies in Europe: experiences from field identification, surveys, and monitoring. Acta Chiropterologica. 1(2): 137-150.

Arlettaz, R., G. Jones, and P.A. Racey. 2001. Effect of acoustic clutter on prey detection by bats. Nature. 414: 742-745.

Barboza, K., M.I. Galarza, L.F. Aguirre, and E.K.V. Kalko. 2006. Protocolo para la utilización del equipo acústico Pettersson para la detección de murciélagos. p. 23-44. In: M.I. Galarza, and L.F. Aguirre (eds.). Métodos estandarizados para el estudio de murciélagos en Bosques Montanos. BIOTA. Cochabamba, Bolivia.

Barboza, K., J.C. Pérez-Zubieta, E.K.V. Kalko, L.F. Aguirre, and G. Ossa. 2009. Importancia del monitoreo acústico en el estudio de comunidades de murciélagos. Simposio presentado en el Primer Congreso sobre investigación y conservación de murciélagos y primera reunión del grupo de especialistas en el Ecuador. Quito, Ecuador. 8-9 Mayo.
Canals, M., J. Iriarte-Diaz, R. Olivares, and F. Novoa. 2001. Comparación de la morfología alar de Tadarida brasiliensis (Chiroptera: Molossidae) y Myotis chiloensis (Chiroptera: Vespertilionidae), representantes de dos diferentes patrones de vuelo. Revista Chilena de Historia Natural 74: 699-704.

Canals, M., and P. Cattan. 2008. Murciélagos de Chile. p. 69-83. In: M. Canals, and P. Cattan (eds.). Radiografía a los Murciélagos de Chile. Editorial Universitaria, Santiago, Chile.

Cleveland, C., M. Betke, P. Federico, J.D. Frank, T.G. Hallam, J. Horn, J. López, G.F. McCracken, R.A. Medellin, A. Moreno-Valdez, CH. Sansone, J. Westbrook, and T.H. Kunz. 2006. Economic value of the pest control service provided by Brazilian Free-tailed bats in south-central Texas. Frontiers in Ecology and the Environment 4(5): 238-243.

Di Castri, F., and E. Hajek. 1976. Bioclimatología de Chile. Imprenta - Editorial de la Universidad Católica de Chile. Santiago, Chile.

Federico, P., T. Hallam, G. McCracken, S. Purucker, W. Grant, A. Correa-Sandoval, J. Westbrook, R. 
Medellin, C. Cleveland, C. Sansone, J. López Jr., M. Betke, A. Moreno-Valdez, and T. Kunz. 2008. Brazilian free-tailed bats as insect pest regulators in transgenic and conventional cotton crops. Ecological Applications 18(4): 826-837.

Fenton, M.B., N.G.H. Boyle, T.M. Harrison, and D.J. Oxley. 1977. Activity patterns, habitat use, and prey selection by some African insectivorous bats. Biotropica 9(2): 73-85.

Fenton, M.B., and G.P. Bell. 1981. Recognition of species of insectivorous bats by their echolocation calls. Journal of Mammalogy 62(2): 233-243.

Galaz J.L., and J. Yáñez. 2006. Los Murciélagos de Chile: Guía para su reconocimiento. Ediciones del Centro de Ecología Aplicada. Santiago, Chile. 80 p.

Galaz, J.L., J. Yáñez., A. Gantz, and D. R. Martínez. 2009. Orden Chiroptera. p. 67-84. In: A. Muñoz-Pedreros and J. Yáñez (eds.). Mamíferos de Chile. CEA Ediciones, Segunda edición. Valdivia, Chile.

Iriarte, A. 2008. Mamíferos de Chile. Lynx Ediciones. Barcelona, España, 420 p.

Jones, G. 1999. Scaling of echolocation call parameters in bats. The Journal of Experimental Biology 202: 3359-3367.

Kalko, E.K.V., and H. Schnitzler. 1989. The echolocation and hunting behavior of Daubenton's bat, Myotis daubentoni. Behavioral Ecology and Sociobiology 24(4): 225-238.

Kalko, E.K.V., and H. Schnitzler. 1993. Plasticity in echolocation signals of European pipistrelle bats in search flight: implications for habitat use and prey detection. Behavioral Ecology and Sociobiology 33(6): 415-428.

Kalko, E.K.V. and L.F. Aguirre. 2007. Comportamiento de ecolocación para la identificación de especies y evaluación de la estructura de comunidades de murciélagos insectívoros en Bolivia. p. 41-53. In: L.F. Aguirre (ed.). Historia natural, distribución y conservación de los murciélagos de Bolivia. Editorial: Centro de Ecología y Difusión Simón I. Patiño. Santa Cruz, Bolivia.

Korine, C., and E.K.V. Kalko. 2001. Toward global bat-signal Database. A standardized protocol for recording and Analysis of bat calls for Worldwide Species Identification. IEE Engineering in Medicine and Biology 20 (3): 81-85.

Kunz, T.H., and P.A. Racey. 1998. Bat biology \& conservation. Smithsonian Institution Press. Washington D.C. 365 p.
LaVal, R.K., and B. Rodríguez-H. 2002. Murciélagos de costa Rica. INBio Ediciones. Instituto Nacional de Biodiversidad, Santo Domingo de Heredia, Costa Rica. 320 p.

MacAdam, V., R. Walker, R. Abarca, T. Venegas, M. Venegas, and R. Sanhueza. 1996. Guía El Cañi. World Wide Fund for Nature \& Fondo de las Américas. 43 p.

Mann, G. 1978. Los pequeños mamíferos de Chile. Gayana Zoología 40: 1-342.

McCracken, G.F. 1996. Bats aloft: A study of highaltitude feeding. Bat Magazine 14(3): 7-10.

MitchellI-Jones, A.J., and A.P. McLeish. 2004. Handling, releasing and keeping bats. p. 63-69. In: A.J. Mitchell-Jones, and A.P. McLeish. (eds.). Bat Workers' Manual. 3rd Edition. Joint Nature Conservation Committee. Peterborough, United Kingdom.

Moya, M.I., M.I. Galarza, A. Vargas and L.F. Aguirre. 2007. Murciélagos de los Yungas de Bolivia. BIOTA ediciones. Cochabamba. Bolivia. 70 p.

Murray, K.L., E.R. Britzke, and L.W. Robbins. 2001. Variation in search-phase calls of bats. Journal of Mammalogy 82(3): 728-737.

Neuweiler, G. 2000. The Biology of Bats. Oxford University Press. New York, United States of America. $303 \mathrm{p}$.

Parsons, S., and G. Jones. 2000. Acoustic identification of twelve species of echolocating bat by discriminant function analysis and artificial neural networks. The Journal of Experimental Biology 203: 2641-2656.

Schnitzler, H., and E.K.V. Kalko. 2001. Echolocation by insect-eating bats. BioScience 51(7): 557-569.

Schnitzler, H., C.F. Moss, and A. Denzinger. 2003. From spatial orientation to food acquisition in echolocating bats. Trends in Ecology and Evolution 18(8): 386-394.

Siemers, B.M., and H. Schnitzler. 2004. Echolocation signals reflect niche differentiation in five sympatric congeneric bat species. Nature 429(10): 657-661.

Siles, L., and M. Terán. 2007. Aplicación del sistema de detección acústica AnaBat en Bolivia. p. 142151. In: L.F. Aguirre (ed.). Historia Natural, Distribución y Conservación de los Murciélagos de Bolivia. Editorial: Centro de Ecología y Difusión Simón I. Patiño. Santa Cruz, Bolivia.

Solís, R. 2008. Ecolocalización en murciélagos. p. 59-68. In: M. Canals, and P. Cattan (eds.). Radiografía a los Murciélagos de Chile. Editorial Universitaria, Santiago, Chile. 
Vargas, A. 2007. Familia Vespertilionidae. Gray, 1821. p. 305-329. In: L.F. Aguirre (ed.). Historia natural, distribución y conservación de los murciélagos de Bolivia. Editorial: Centro de Ecología y Difusión Simón I. Patiño. Santa Cruz, Bolivia.

Walsh A., and C. Catto. 2004. Survey and Monitoring. p. 29-39. In: A.J. Mitchell-Jones and A.P. McLeish. (eds.). Bat Workers' Manual. 3rd Edi- tion. Joint Nature Conservation Committee. Peterborough, United Kingdom.

Wickramasinghe, L., S. Harris, G. Jones and N. Vaughan. 2004. Abundance and Species Richness of Nocturnal Insects on Organic and Conventional Farms: Effects of Agricultural Intensification on Bat Foraging. Conservation Biology 18(5): 1283-1292. 
